\title{
Detransitivization Strategy and the Indonesian Middles
}

\author{
I Nyoman Udayana*
}

\author{
Faculty of Humanities, Udayana University \\ *Corresponding author. Email: nyoman_udayana@unud.ac.id
}

\begin{abstract}
Middles cross-linguistically are commonly defined as syntactic operations which behave in an intermediate way between actives and passives. The associated verbs that enter into middles are intransitive. However, there are cases where the verbs needed for the middles are conceptual-semantically divalent. I argue that the Indonesian middles which may contain semantically divalent verbs can participate in them utilizing detransitivization strategy. The study gathered the data found in Leipzig corpora. The collected data are then divided related to their lexical arity properties. The verbs that semantically belong to monovalent verbs and those associated with divalent verbs, it is found out that while actives and passives in Indonesian have different marking respectively, the Indonesian middles are invariably marked with the ber-form. The ber-forms which are markers of intransitive verbs make the middles invariably monovalent while the divalent verbs are turned into intransitive ones leading to a syntax-semantics mismatch, that is, the associated middle verbs which are semantically divalent are made syntactically monovalent.
\end{abstract}

Keywords: middles, divalent, syntax-semantics mismatch, detransitivization strategy

\section{INTRODUCTION}

Cross-linguistically, middles are divided into two types. The first type covers constructions whose middles are marked on the verb while the second type has to do with construction or clauses which do not have the marking on the verbs. The first type is called middle voice and the second one is referred to simply as middle constructions in the literature.

Middles are defined as a construction that is intermediate between actives and passives [1]. The intermediate status of middles suggests that languages that have middle marking can have different markings for actives, passives, and middles. Indonesian agrees with these characteristics, as illustrated in (1). The active verbs are marked with the affix $m e N$ - which is glossed as Agentive Voice (AV), the passive verb is marked with the $d i$-affix on the verb which is glossed as PASSIVE (PAS), and finally, the middle marker on the verb is marked with ber- which is glossed as Middle Voice (MV).

(1) a. Dia menjual buku
3SG AV.sell book

'(S)he sold a book b. Buku itu dijual oleh dia book that PAS.sell 3SG 'The book was sold by him/her'

c. Buku itu berjual book that MV.sell

'The book sells'

However, Kemmer's [2] observation, which deals with a middle voice across languages, finds that middle voice constructions can be in the form of intransitive constructions. That is a construction that contains one core argument. Her discussion includes Indonesian, as illustrated in (1). The middles that are associated in Kemmer classification that have the occurrence of a purely intransitive verb in Indonesian includes what she calls the change of body posture middles, translational motion middles, cognitive middles, and middles denoting spontaneous event. She comes to this classification based on her cross-linguistic observation of middles (with middle marking).

Change of body posture berlutut 'kneel down'

Translational motion berjalan 'run' Cognitive middle 


\author{
berpikir 'think' \\ Spontaneous event \\ berhenti 'put to a stop'
}

\section{METHODOLOGY}

The data for the study are analyzed descriptively. Naturally occurring expressions are expected to be used in the study. The examples for the analysis were obtained from Leipzig corpora. However because the glossing is not available in the corpora, it was given by the author himself. In addition, since not all the examples provided are available in Leipzig corpora, the author has taken the liberty of supplying each example whose (un)acceptability judgments come from other native speakers of Indonesian.

\section{ANALYSIS}

With middle constructions in Indonesian which are uniformly monadic in terms of their semantic structure, detransitivizing strategy is a common practice. Let us first have a look at the patientive middles which as the name implies the sole argument of the verb in question receives a patient role. This is much like the transformation of an active clause into its corresponding passive clause in which the patient argument which used to occupy an object position in the active clause is promoted to a subject position.

(6) Aku mengirim pesan melalui

$1 \mathrm{SG}$ AV.send message through

emailnya

email.3POSS

'I sent a message through his email.

(7) Pesan dikirim melaui emailnya

message PAS.send through email.3POSS

(oleh aku)

(by $1 \mathrm{SG}$ )

'The message was sent through his email (by me)'

(8) Pesan itu berkirim melalui

message that MV.send through

emailnya

email.3POSS

'The message sends through his email'

The basic structure is the active clause. The passive in (7) and the middle in (8) are in some sense derived from the basic structure. The two derived clauses can be said to be packaged to surface as passive and middle. The two clauses are significantly different from each other. The agent of the passive clause, although it is optional on the surface structure, it is still semantically preserved. Therefore, it does not come as a surprise that the active and its corresponding passive clause still hold the same conceptual meaning. This can be proven by the fact that the agent-oriented test that is used to indicate the involvement of an agent in the passive clause proper, i.e. the volitionality phrase dengan sengaja 'intentionally' still renders the resulting sentence acceptable, as shown in (9a) while an attempt to make the same purpose for the middle construction in (9b) yields an ill-formed construction.

(9) a. Pesan itu dikirim melalui message that PAS.send through emailnya dengan sengaja email.3SGPOSS with purpose 'The message was sent through his email intentionally'

b. *Pesan itu berkirim melalui message that MV.send through emailnya dengan sengaja email.3SGPOSS with purpose 'The message sends through his email intentionally

The test to show that the passive clause is different from the middle construction is the by-phrase test. The occurrence of by phrase in a passive construction as in does not pose any problem [3]; [4]; [5]. However, the attachment of the same by phrase to the patientive middles is odd [6]; [7]; as illustrated in (10b).

(10) a. Pesan itu dikirim melalui message that PAS.send through emailnya oleh aku email.3SGPOSS by $1 \mathrm{SG}$

'The message was sent through his email by me'.

b. *Pesan itu berkirim melalui message that MV.send through emailnya oleh aku

email.3SGPOSS by $1 \mathrm{SG}$

'The message sends through his email by me'.

The next test involves control into a purposive clause. The idea is that the underlying clause, the active clause, which produces an intention indicates that the agent has some purpose to instigate an action therefore an intention is inherent in the action denoted by the predicate. Again, the attachment of a purposive clause to a passive clause results in grammaticality. However, to do the same for the middle construction makes the resulting sentence ungrammatical.

(11) a. Buku itu dikirim untuk mendapatkan book that PAS.send to AV.get pengganti replacement

'The book was sent to get replacement'

b. *Buku itu berkirim untuk mendapatkan book that MV.send to AV.get pengganti replacement

'The book send to get replacement' 
The next detransitivization strategy concerns what is called the agentive middles which are similar to the patientive middle in that it has only one argument but predictably the sole argument as the name suggests is realized by an agent role. This instance of middles is commonly exemplified by grooming middles, as in (12)', and emotional middles as in (13)' and (14)'. These middles are characterized by reflexive constructions in the active constructions and consequently, the middle counterparts are also reflexive. This phenomenon showing the relationship between reflexives and middles is universal. Notice that being agentive, the middles can take the agent-oriented adverb dengan sengaja 'intentionally' in (15b), (16b), and (17b).

(12) Dia mendandan diri

3SG AV.dress self

'She dressed herself'

(12) Dia berdandan (diri)

3SG MV.dress self

'She got dressed'

(13) John menyedihkan diri

John AV.sad.CAUS self

'John saddened himself'

(13)` John bersedih (diri)

John MV.sad (self)

'John saddened himself'

(14) Anita mendiamkan diri

Anita AV.silence self

'Anita silenced herself'

(14)' Anita berdiam (diri)

Anita MV.silent (self)

'Anita silenced herself'

(15) a. Dia mendandan diri denga

3SG AV.dress self with

sengaja

purpose

'She dressed herself on purpose'

b. Dia berdandan (diri) dengan sengaja

3SG MV.dress self with purpose

'She dressed herself on purpose'

(16) a. Dia menyabarkan diri

3SG AV.patient.CAUSE self

dengan sengaja

with purpose

'(S)he made himself/herself patient on purpose'

b. Dia bersabar diri dengan sengaja

3SG MV.patient self with purpose

'(S)he made himself/herself patient on purpose'

(17) a. Dia mendiamkan diri dengan sengaja 3SG AV.silence self with purpose '(S)he silenced himself/herself on purpose'

\section{b. Dia berdiam diri dengan segaja 3SG MV.silent self with purpose \\ '(S)he silencd himself/herself on purpose'}

The next point of syntax-semantics observation found in Kemmer [2] is the notion of the middle that has to do with what she calls logophoric middles. However, before we come to further analysis about this aspect of middles, in what follows, it is better to briefly explicate the concept of logophoricity.

Logophoricity deals with an indirect discourse structure. The pronoun that appears in languages with a logophoric system is called the logophoric pronoun. Logophoric pronouns appear in the clausal complement of a predicate that licenses logophoricity, ie. verbs of communication, and this pronoun finds its antecedent in these verbs [8]; [9]; [10]; [11]; [12]). Pure logophoric pronouns are found in languages of West African languages (18a) shows that logophoric pronoun in Ewe has its special form distinct from a regular pronoun. In Gokana (19b), a logophoric pronoun has the same form as a regular pronoun. Logophoicity is marked on the verb. Thus, the subject NP that serves as the argument of logophorically-marked verb is interpreted as a logophoric pronoun.

Ewe (Clements [10]):

(18) a. Kofi be yè-dzo.
Kofi say Log-leave
'Kofi $i_{i}$ said that he $e_{i}$ left.'
b. Kofi be e-dzo.
Kofi say Pro-leave
'Kofi ${ }_{i}$ said that he heft.' $_{j}$ left

Gokana (Hyman and Comrie [13]):

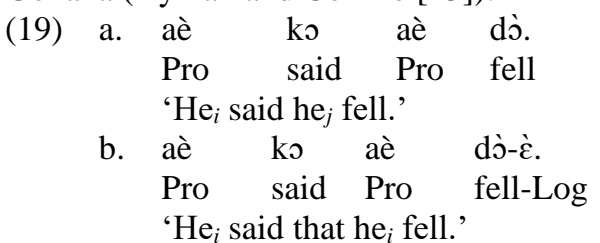

In languages outside West Africa commonly found in Asia (including Indonesian) and Europe the logophoric pronoun is derived from reflexive anaphor [14]. Therefore the lexical item dirinya in both (a) and (b) serves as indicating logophoric anaphor on a par with the lexical item (logophor) found in Ewe. Middles that relate to the notion of logophority, based on Kemmer's [2] observation have to do with the verbs that license logophoricity. This type of verbs exhibits the transitive-intransitive alternation, thereby qualifying for the intransitive form to be marked with ber-affix, the middle marker. To show the alternation, the active verbs with $m e N$-forms can undergo passivization in which the dependent clause being an object in (20-21) can occupy the subject position as shown in (22a-b) although for some speakers the sentences in (22a-b) might sound a bit awkward. Out of the detransitivizing process, the logophoric middles are achieved, as illustrated in (23ab). 
(20) Dia mengatakan bahwa dirinya

3SG AV.say COMP self.3POSS

tidak akan datang

NEG FUT come

'(S)he said that he/she will come

(21) Tono menanyakan apakah dirinya akan Tono AV.ask COMP self.3SG FUT memenangi kejuaraan itu AV.win competition that

'Tono asked if he would win the competition'

(22) a. Bahwa dirinya tidak akan

COMP self.3SGPOSS NEG FUT

datang dikatakan oleh dia

come PAS.say by 3SG

'That (s)he would come was said by him/her'

b. Apakah dirinya akan

COMP self.3SGPOSS FUT

memenangi kejuaraan itu

AV.win competition that

ditanyakan oleh Tono

PAS.say by Tono

'Whether (s)he would win the competition was asked by Tono'.

(23) a. Dia berkata bahwa dirinya

3SG MV.say COMP self.3POSS

tidak akan datang

NEGFUT come

'(S)he said that (s)he will not come'

b. Tono bertanya apakah dirinya

Tono MV.ask COMP self.3SG

akan memenangi kejuaraan itu

FUT AV.win competition that

'Tono believes that he will win the competition'

\section{CONCLUSION}

This small paper has shown that middle voice constructions can be realized by a pure intransitive verb, meaning that the base verbs that appear in the verbal predicate are monovalent. However, the verb base can be divalent making a situation such that there is a syntax-semantics mismatch. The verb is semantically divalent but syntactically it is turned into a monovalent structure. Several categories are associated with this such as patientive passive middles and agentive middles. The former are constructions whose sole argument, as the name suggests, is realized by a subject that receives a patient role while the latter the subject of the clause is realized by an agent role. Middles may enter into the logophoric system indicated by the fact that the verb that licenses it is middle-marked.

\section{AUTHORS' CONTRIBUTIONS}

The author obtains the concept of middles mainly from Kemmer [2] and incorporates the argument realization of the Indonesian verbal predicates into the analysis of the middle voice in Indonesian.

\section{ACKNOWLEDGMENTS}

Our thanks are due to Dr Juffrizal from the State University of Padang and all the audience at the International Conference of Linguistic Society of Indonesia (KIMLI) 2021 for their comments and suggestions.

\section{REFERENCES}

[1] Matthews, Peter H. (2007). Concise dictionary of linguistics. Oxford: Oxford University Press.

[2] Kemmer, Suzanne. (1993). The middle voice. Amsterdam: John Benjamins Publishing Company.

[3] Alexiadou, Artemis. (2012). 'Non-canonical passives revisited: Parameters of non-active voice'. Linguistics 50(6): 1079-1110

[4] Alexiadou, Artemis and Florian Schäfer (eds.) 2013. Non-canonical passives. John Benjamins Amsterdam: Publishing Company.

[5] Lyngfelt, Benjamin \& Solstad, Torgrim (eds.). 2006. Demoting the agent: Passive, middle, and other voice phenomena. Amsterdam: John Benjamins Publishing Company.

[6] Condoravdi, C. (1989). The Middle: Where Semantics and Morphology Meet. In MIT Working Papers in Linguistics 11, 18-30. Cambridge, MA: The MIT Press.

[7] Steinbach, Markus. (2002). Middle voice: A comparative study in the syntax-semantics interface of German. Amsterdam: John Benjamins Publishing Company.

[8] Hagège, Claude. (1974). Les pronoms logophoriques. Bulletin de la société de linguistique de Paris 69. 287-310.

[9] Sells, Peter. (1987). Aspects of logophoricity. Linguistic Inquiry 18: 445-479.

[10] Clements, George N. (1975). The logophoric pronoun in Ewe: Its role in discourse. Journal of West African Languages 10. 141-77

[11] Culy, Christopher. (1994). Aspects of logophoric marking. Linguistics 32. 1055-1094.

[12] Culy, Christopher. (1997). Logophoric Pronouns and Point of View. Linguistics, 35: 845-859.

[13] Hyman, Larry M. \& Comrie, Bernard. (1981). Logophoric reference in Gokana. Journal of African Languages and Linguistics 3. 19-37.

[14] Huang, Yan. (2000). Anaphora: A crosslinguistic study. Oxford: Oxford University Press. 